\title{
Thermodynamic Studies on $\mathrm{Ba}_{3} \mathrm{SrNb}_{2} \mathrm{O}_{9}$ Employing Calorimeter
}

\author{
Pradeep Samui*, Brij Mohan Singh, Hemlata V. Khadilkar, Swarup K. Rakshit, Suresh C. Parida \\ Product Development Division, Bhabha Atomic Research Centre, Trombay, Mumbai, India, PIN - 400085 \\ Homi Bhabha National Institute, BARC, Mumbai-85) \\ E-mail: *pradeepsamui@gmail.com
}

Received 17 May 2021, Revised 21 July 2021, Accepted 19 August 2021

\begin{abstract}
In this study, $\mathrm{Ba}_{3} \mathrm{SrNb}_{2} \mathrm{O}_{9}$ (s) was synthesized using conventional solid-state reaction route, characterized by powder XRD and SEM-EDAX. The standard molar enthalpy of formation of $\mathrm{Ba}_{3} \mathrm{SrNb}_{2} \mathrm{O}_{9}$ (s) was determined measuring enthalpies of solution of $\mathrm{Ba}_{3} \mathrm{SrNb}_{2} \mathrm{O}_{9}$ (s) in $\left\{\mathrm{PbO}+\mathrm{B}_{2} \mathrm{O}_{3}\right\}$ solvent (in 2:1 molar ratio) at $T=966 \mathrm{~K}$ using an oxide melt solution high temperature calorimeter. The enthalpy increment of $\mathrm{Ba}_{3} \mathrm{SrNb}_{2} \mathrm{O}_{9}$ (s) was measured with same calorimeter. The heat capacity of the $\mathrm{Ba}_{3} \mathrm{SrNb}_{2} \mathrm{O}_{9}$ (s) was also measured employing DSC. Based on the smoothed values of heat capacity, a table of thermodynamic data from 298 to $1000 \mathrm{~K}$ for $\mathrm{Ba}_{3} \mathrm{SrNb}_{2} \mathrm{O}_{9}$ (s) was also constructed.
\end{abstract}

Keywords: Heat capacity; dsc; high temperature calorimeter; enthalpy of formation; niobates.

\section{Introduction}

During the fission of Mixed OXide (MOX) fuel e.g. $\left(\mathrm{U}_{\mathrm{x}} \mathrm{Pu}_{1-\mathrm{x}}\right) \mathrm{O}_{2} ; \mathrm{Ba}, \mathrm{Sr}$ and $\mathrm{Nb}$ are produced among other fission products. They can form ternary or higher order oxides in an operating nuclear reactor with oxide fuels under certain oxygen potential. Evaluations of thermodynamic functions of these oxides are therefore, important for assessment of fission product interactions and modeling of fuel. Furthermore, thermodynamic data of these oxides are also of relevance because of computation of phase diagram and phase stability of pseudo-ternary system $\mathrm{BaO}-\mathrm{SrO}-\mathrm{Nb}_{2} \mathrm{O}_{5}$ and $\mathrm{BaO}-\mathrm{SrO}-\mathrm{Nb}_{2} \mathrm{O}_{5}-\mathrm{B}_{2} \mathrm{O}_{3}$ etc, in which some of the compounds are potential candidate materials for microwave ceramics with high dielectric constant, electro-optic, pyroelectric and piezoelectric devices [1-10]. Strontium barium niobate (SBN) are also promising candidate as a ferroelectric glass ceramic material. Carruthers and Grasso [11] experimentally investigated the phase equilibria relation in $\mathrm{BaO}-\mathrm{SrO}$ $\mathrm{Nb}_{2} \mathrm{O}_{5}$ system. In this system, compounds having composition $\left(\mathrm{Ba}_{5-\mathrm{x}} \mathrm{Sr}_{\mathrm{x}}\right) \mathrm{Nb}_{4} \mathrm{O}_{15}$, possesses high permittivity and low loss in the microwave frequency region [12]. More recently, a structure refinement of $\mathrm{Ba}_{3} \mathrm{SrM}_{2} \mathrm{O}_{9}(\mathrm{M}=\mathrm{Nb}, \mathrm{Ta})$ has been reported [13]. It has modified hexagonal $\mathrm{BaTiO}_{3}$ type structure, where the entire octahedral are skewed around their threefold axis and $\mathrm{Nb}(\mathrm{V})$ ions occupy the facesharing octahedral [13]. However, thermodynamic data of this compound is not available in the literature. As a part of programme to study the thermodynamic properties of fission product compounds, we have report thermodynamic data of $\mathrm{Ba}_{3} \mathrm{SrNb}_{2} \mathrm{O}_{9}$ (s) compound.

In present research, the enthalpy of formation of $\mathrm{Ba}_{3} \mathrm{SrNb}_{2} \mathrm{O}_{9}$ (s) compound was determined using high temperature solution calorimeter. The enthalpy increment and high temperature heat capacity values of the $\mathrm{Ba}_{3} \mathrm{SrNb}_{2} \mathrm{O}_{9}(\mathrm{~s})$ compound were also measured using high temperature calorimeter and differential scanning calorimeter, respectively.

\section{Experimental procedure}

\subsection{Synthesis of compounds and characterization}

The starting materials used for preparation of $\mathrm{Ba}_{3} \mathrm{SrNb}_{2} \mathrm{O}_{9}(\mathrm{~s})$ powders using solid state reaction route for the present study were $\mathrm{BaCO}_{3}$ (Alfa Aesar, mass fraction 0.9995), $\mathrm{SrCO}_{3}$ (Alfa Aesar, mass fraction 0.9995) and $\mathrm{Nb}_{2} \mathrm{O}_{5}$ (Alfa Aesar, mass fraction 0.999). $\mathrm{BaCO}_{3}$ and $\mathrm{SrCO}_{3}$ were first dried in $\mathrm{Ar}$ at $200^{\circ} \mathrm{C}$ for $8 \mathrm{~h}$ prior mixing. Stoichiometric amount of carbonates and $\mathrm{Nb}_{2} \mathrm{O}_{5}$ were properly mixed using an agate mortar and made into pellets. The pellet was taken in a platinum boat and it was then heated at $900 \mathrm{~K}$ inside a muffle furnace, for a period of 120 h. Finally, the above-mentioned pellets were powdered and pressed into pellets, and then the samples were sintered at $1300 \mathrm{~K}$ for $48 \mathrm{~h}$. Phase formation and lattice parameters of $\mathrm{Ba}_{3} \mathrm{SrNb}_{2} \mathrm{O}_{9}(\mathrm{~s})$ were determined by powder $\mathrm{X}$-ray diffraction technique using the $\mathrm{Cu}-\mathrm{K} \alpha$ radiation $(\lambda=1.5418$ $\AA$ ) to ascertain the phase purity of the compound. For this, a Miniflex 600 X-ray diffractometer (Model: Rigaku, Japan) using graphite monochromatized $\mathrm{Cu} K \alpha_{1}$ radiation $(\lambda=$ $0.15406 \mathrm{~nm}$ ) was used. The diffraction data $\mathrm{g}$ was scanned in the range $10^{\circ}<2 \Theta<60^{\circ}$ with a step of $0.01^{\circ}$ and $0.3 \mathrm{~s}$ dwell time.

The surface morphology of the $\mathrm{Ba}_{3} \mathrm{SrNb}_{2} \mathrm{O}_{9}$ (s) ceramic powders was investigated by Scanning Electron Microscopy (SEM, JEOL Ltd., JSM-5910LV) equipped with EDS after gold coating.

\subsection{High temperature solution calorimetry}

The determination of the standard molar enthalpy of formation of $\mathrm{Ba}_{3} \mathrm{SrNb}_{2} \mathrm{O}_{9}(\mathrm{~s})$ involved two kinds of calorimetric measurements. The standard molar enthalpy of formation of $\mathrm{Ba}_{3} \mathrm{SrNb}_{2} \mathrm{O}_{9}$ compound was determined by measuring the enthalpy change for the dissolution of $\mathrm{Ba}_{3} \mathrm{SrNb}_{2} \mathrm{O}_{9}$ and its starting materials such as $\mathrm{BaCO}_{3}(\mathrm{~s})$, $\mathrm{SrCO}_{3}(\mathrm{~s})$ and $\mathrm{Nb}_{2} \mathrm{O}_{5}(\mathrm{~s})$ in liquid $\left\{\mathrm{PbO}+\mathrm{B}_{2} \mathrm{O}_{3}\right\}$ solvent (in 2:1 molar ratio) at $966 \mathrm{~K}$ using Alexsys high temperature 
calorimeter (Setaram, France). For the sake of better understanding, schematic of calorimeter has been represented in Figure 1.

$\sim \mathrm{g}$ of $\left\{\mathrm{PbO}+\mathrm{B}_{2} \mathrm{O}_{3}\right\}$ solvent (in 2:1 molar ratio) was taken in platinum crucible during each experiment. The heat flow signal in microvolt as a function of time was measured. The change in enthalpy per unit mass of solute indicates the infinite dilute condition and composition independency during the experiment. Three sets of solubility experiments for each solute were carried out to check consistency of the experimental data. The calibration of the calorimeter was carried out by adding small pieces of synthetic sapphire [NIST SRM-720] from ambient temperature into reaction platinum crucible, maintained at $966 \mathrm{~K}$ [15]. The weight of the sample and synthetic sapphire [NIST SRM-720] was in the range 20-30 and 30$50 \mathrm{mg}$, respectively. The accuracy of the instrument obtained by using enthalpy increment values of high purity molybdenum ( $99.997 \%$ purity) and NBS standard synthetic sapphire (SRM 720) was better than $\pm 2 \%$.

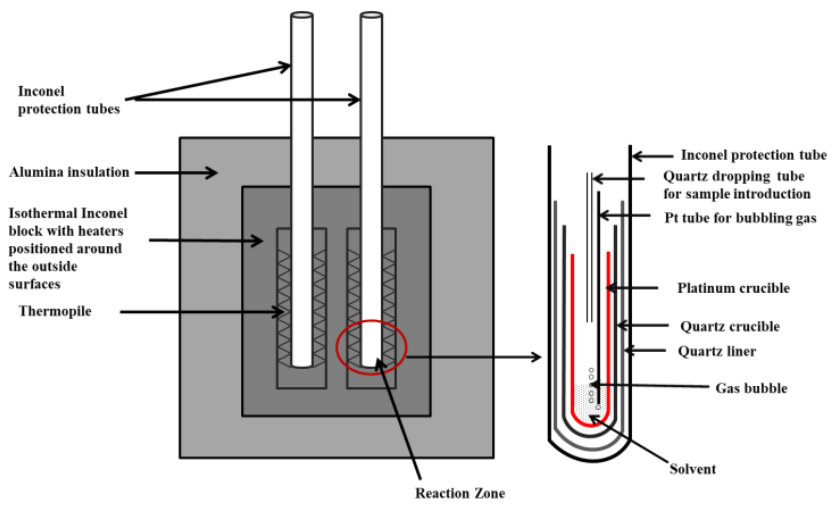

Figure 1. Schematic of high-temperature Calvet-type solution calorimeter (Alexsys-1000, make SETARAM, France).

\subsection{Measurement of heat capacity using differential scanning calorimeter}

A standard three step method i) blank-blank, ii) blankreference and iii) blank-sample was followed for the determination of the heat flow rate signal of base line, reference vs. signal and sample vs. signal, respectively. Heat capacity measurements of $\mathrm{Ba}_{3} \mathrm{SrNb}_{2} \mathrm{O}_{9}$ (s) were carried out in a platinum crucible with lids using Labsys Evo1600 simultaneous thermal analyzer system (Setaram Instrumentation, France) in $C_{p}$ mode. The flow rate of 30 $\mathrm{mL} \cdot \mathrm{min}^{-1}$ of dry argon (purity, $99.9999 \%$ ) and heating rate of furnace at $5 \mathrm{~K} \cdot \mathrm{min}^{-1}$ with continuous scanning mode was maintained during all measurements. The phase transition temperature of standard reference materials $\mathrm{In}, \mathrm{Sn}, \mathrm{Pb}, \mathrm{Al}$ and $\mathrm{Ag}$ under the scanning rate of 2,5 and $10 \mathrm{~K} \cdot \mathrm{min}^{-1}$ was measured for the temperature calibration of the DSC. A temperature correction factor as a function of heating rate was plotted and the value corresponding to zero heating rate was obtained. The corrected temperature was used for the heat capacity measurement of the compound. $400.0( \pm 0.1)$ mg of $800 \mathrm{~K}$ sintered sample of $\mathrm{Ba}_{3} \mathrm{SrNb}_{2} \mathrm{O}_{9}(\mathrm{~s})$ powder was taken into the platinum crucible for measurement. NIST synthetic sapphire (SRM-720, mass fraction purity 0.9999) sample was used as reference material with known heat capacity values taken from the literature $[15,16]$. The values of heat capacity of Zirconia (Alfa Aesar, USA, mass fraction 0.99978) were measured in the same temperature range to check the accuracy of the calorimeter which was found to be within $\pm 2 \%$ compared to the literature values [16].

\subsection{High temperature enthalpy increment}

High temperature enthalpy increment measurements of $\mathrm{Ba}_{3} \mathrm{SrNb}_{2} \mathrm{O}_{9}$ (s) were carried out using same hightemperature calorimeter without solvent as given in Figure 1. Each measurement involved at least three consecutive drops of the pellets of the sample and the pieces of the synthetic sapphire $\alpha-\mathrm{Al}_{2} \mathrm{O}_{3}$ (SRM-720) in a constant flow of argon gas (purity, 99.9995\%). The calibration of the calorimeter was found by comparing the peak area of $\alpha$ $\mathrm{Al}_{2} \mathrm{O}_{3}$ with literature values of enthalpy increment data for $\alpha-\mathrm{Al}_{2} \mathrm{O}_{3}$ [15]. At each isotherm, the enthalpy increment values were calculated by taking mean of the values of at least three individual sample drops.

\section{Result and Discussion \\ 3.1 Characterization}

The purity of $\mathrm{Ba}_{3} \mathrm{SrNb}_{2} \mathrm{O}_{9}$ (s) powder was ascertained by using X-ray diffraction (XRD) analysis. The XRD pattern of the sample is shown in Figure 2. The XRD patter of the sample is in well agreement with that of diffraction line of compound given in the reference (JCPDS XRD file No. 351157) [17]. The compound crystallizes in the orthorhombic type structure, space group $\mathrm{Pb} / \mathrm{ca}$ (No. 61) with the cell parameters $\mathrm{a}=\mathrm{b}=6.0649(2) \AA$ and $\mathrm{c}=15.3705(5) \AA$ and were found to be in well agreement with that of reported cell parameters such as $\mathrm{a}=\mathrm{b}=6.0648(1) \AA$ and $\mathrm{c}=$ 15.3703(3) Å [17]. Presence of starting material phases and other unwanted phases were not observed in XRD pattern of the compound.

In SEM analysis, the single phase of $\mathrm{Ba}_{3} \mathrm{SrNb}_{2} \mathrm{O}_{9}(\mathrm{~s})$ compound was observed without any impurity phase. The SEM picture of $\mathrm{Ba}_{3} \mathrm{SrNb}_{2} \mathrm{O}_{9}(\mathrm{~s})$ is shown in Figure $3 \mathrm{a}$. Elemental analysis of synthesized sample was carried out using EDS technique which is already connected to SEM instrument (Figure $3 \mathrm{~b}$ ). The $\mathrm{Ba}, \mathrm{Sr}$ and $\mathrm{Nd}$ atomic ratio obtained from EDS analysis was found to be the same as the formulae ratio of these metals present in the $\mathrm{Ba}_{3} \mathrm{SrNb}_{2} \mathrm{O}_{9}(\mathrm{~s})$. The accuracy of EDS analysis is equal to $\pm 2 \%$.

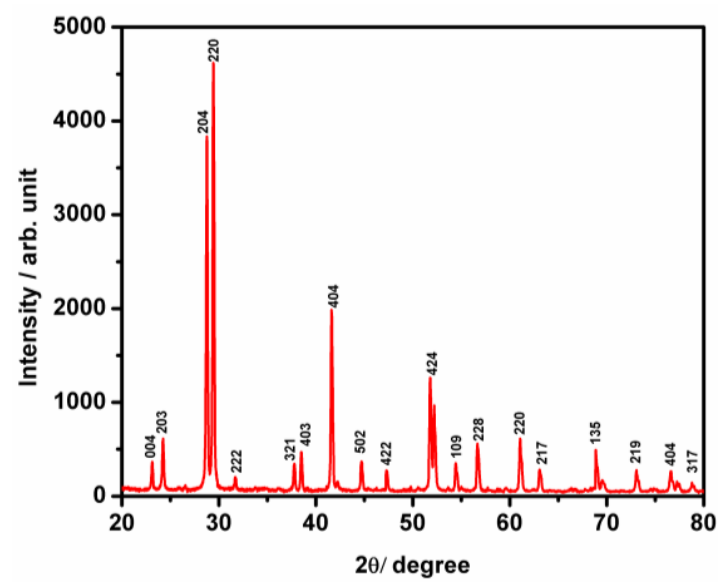

Figure 2. Powder XRD pattern of $\mathrm{Ba}_{3} \mathrm{SrNb}_{2} \mathrm{O}_{9}(s)$.

The phase purity of $\mathrm{Ba}_{3} \mathrm{SrNb}_{2} \mathrm{O}_{9}(\mathrm{~s})$ is confirmed from results of all characterization techniques. The percentage of elemental composition of $\mathrm{Ba}, \mathrm{Sr}$ and $\mathrm{Nd}$ metals are given in Table 1. 
Table 1. Elemental composition of $\mathrm{Ba}, \mathrm{Sr}$ and $\mathrm{Nb}$ from $\mathrm{EDS}$ spectrum.

\begin{tabular}{lll}
\hline Element & EDS (At\%) & Theor.(At\%) \\
\hline $\mathrm{Ba}$ & 50.2 & 48.9 \\
$\mathrm{Sr}$ & 16.5 & 15.5 \\
$\mathrm{Nb}$ & 33.3 & 35.6 \\
\hline Total & 100 & 100 \\
\hline
\end{tabular}
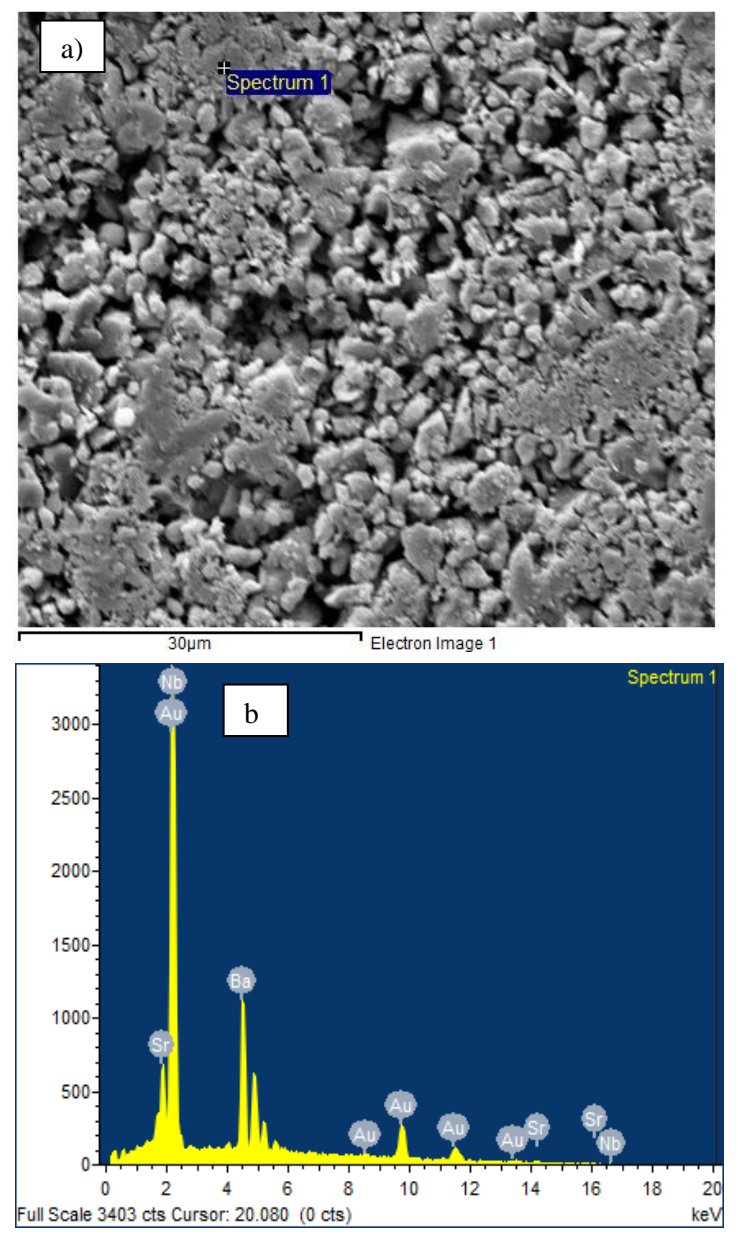

Figure 3. SEM-EDS analyses of $\mathrm{Ba}_{3} \mathrm{SrNb}_{2} \mathrm{O}_{9}$ a) SEM micrograph at $\times 5000$ magnification, b) EDS spectrum.

\subsection{High-temperature enthalpy increment}

The mean of enthalpy increment data of the compound from three set of experiments at each temperature is given in Table 2, along with corresponding measurement errors. The relative deviation (RD\%) between experimental and calculated enthalpy increments was found to better than $2 \%$. The least square fitting of experimental values of enthalpy increment as function of temperature is given in Eq. (1).

$H(T)-H(298)\left(\mathrm{J} \cdot \mathrm{mol}^{-1}\right)( \pm 2 \%)=-118256+340.77 \times T+$ $0.03728 \times T^{2}+3991943.6 / T$

The two boundary conditions were used during fitting (i) enthalpy increment value is zero at $298.15 \mathrm{~K}$ and (ii) heat capacity of the compound is $319.3 \mathrm{~J} \cdot \mathrm{mol}^{-1} \cdot \mathrm{K}^{-1}$, at $298.15 \mathrm{~K}$. The heat capacity at $298.15 \mathrm{~K}$ for the compound was taken from the calculated heat capacity using NeumanKopp's additivity method [16]. The enthalpy increment values from experimental and fitted values are plotted in Figure 4.

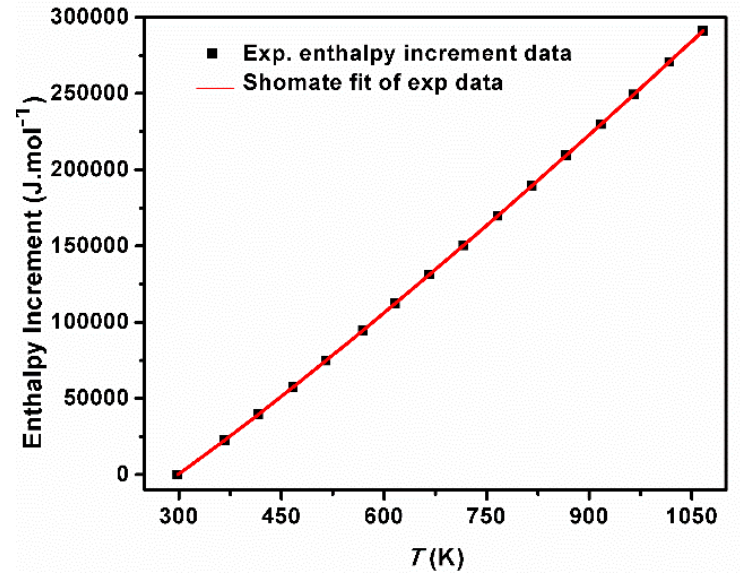

Figure 4. Enthalpy increment of $\mathrm{Ba}_{3} \mathrm{SrNb}_{2} \mathrm{O}_{9}$ compound.

Table 2. Comparison of experimental and calculated enthalpy increment data of $\mathrm{Ba}_{3} \mathrm{SrNb}_{2} \mathrm{O}_{9}$.

\begin{tabular}{cccc}
\hline$T(\mathrm{~K})$ & $\begin{array}{c}H(T)-H(298) \\
(\mathrm{exp})\left(\mathrm{J} . \mathrm{mol}^{-1}\right)\end{array}$ & $\begin{array}{c}H(T)-H(298) \\
(\mathrm{Calc})\left(\mathrm{J} . \mathrm{mol}^{-1}\right)\end{array}$ & $\mathrm{RD} \%$ \\
\hline 298 & - & 0 & - \\
367 & 22817.5 & 22705.0 & 0.5 \\
416 & 39450.9 & 39551.9 & 0.3 \\
467 & 57393.8 & 57562.0 & 0.3 \\
515 & 74500.9 & 74879.5 & 0.5 \\
569 & 94775.6 & 94727.7 & 0.1 \\
616 & 112275.5 & 112284.9 & 0.0 \\
666 & 131372.5 & 131226.5 & 0.1 \\
716 & 149350.6 & 150422.5 & 0.7 \\
766 & 169135.5 & 169859.5 & 0.4 \\
816 & 190959.9 & 189527.5 & 0.8 \\
866 & 208773.5 & 209418.8 & 0.3 \\
917 & 230078.1 & 229931.7 & 0.1 \\
965 & 248578.2 & 249439.8 & 0.3 \\
1017 & 268280.9 & 270790.6 & 0.9 \\
1066 & 289646.3 & 291113.0 & 0.5 \\
\hline
\end{tabular}

\subsection{Measurement of heat capacity}

The molar heat capacity of $\mathrm{Ba}_{3} \mathrm{SrNb}_{2} \mathrm{O}_{9}$ (s) was measured in the temperature range from $350 \mathrm{~K}-900 \mathrm{~K}$. Change of heat capacities values of the $\mathrm{Ba}_{3} \mathrm{SrNb}_{2} \mathrm{O}_{9}$ was plotted as a function of temperature and shown in Figure 5. Best of our knowledge the heat capacity values of $\mathrm{Ba}_{3} \mathrm{SrNb}_{2} \mathrm{O}_{9}$ (s) is not available in literature. Least square fitting of individual values of heat capacities in the temperature interval $350 \mathrm{~K}-900 \mathrm{~K}$, is represented as $C_{\mathrm{p}, \mathrm{m}}^{\mathrm{o}}\left(\mathrm{J} \cdot \mathrm{mol}^{-1} \cdot \mathrm{K}^{-1}\right)=(340.7 \pm 0.6)+(0.075 \pm 0.001) \times(T / \mathrm{K})-$
$(3991943.6 \pm 53751.1) /(T / \mathrm{K})^{2} \quad(350 \leq T / \mathrm{K} \leq 900)$

The heat capacity of $\mathrm{Ba}_{3} \mathrm{SrNb}_{2} \mathrm{O}_{9}$ (s) at $298 \mathrm{~K}$ is estimated using Neuman-Kopp's additivity method [16] and the value is found to be $319.3 \mathrm{~J} \cdot \mathrm{mol}^{-1} \cdot \mathrm{K}^{-1}$ which is in good agreement with the extrapolated values calculated from fitted heat capacity values in Eq. (2). The experimental heat capacity values and estimated NeumannKopp's values of heat capacity of the compound are shown in the Figure 5. It can be seen that the heat capacity values obtained directly from DSC is slightly higher than the values calculated using Neumann-Kopp's rule of additivity. 


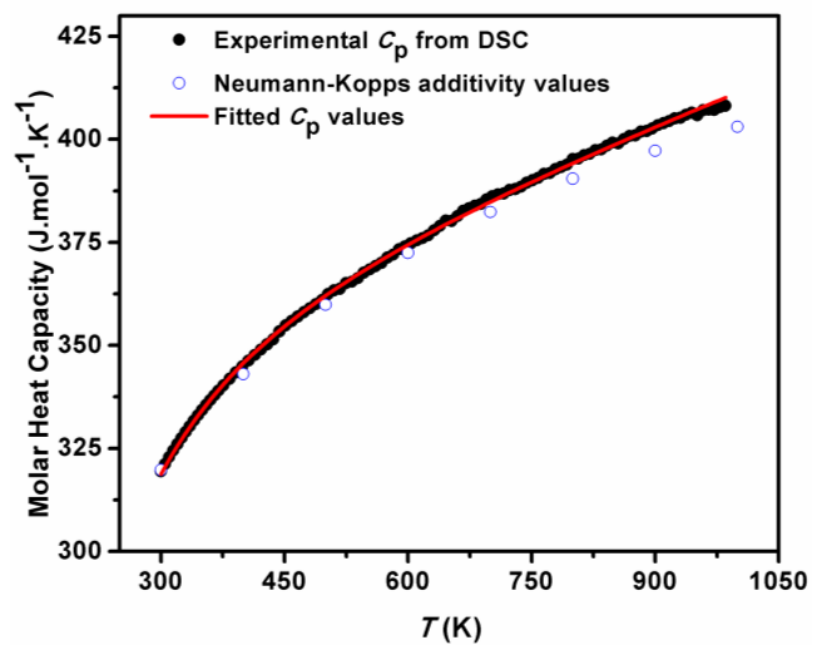

Figure 5. Heat Capacity of $\mathrm{Ba}_{3} \mathrm{SrNb}_{2} \mathrm{O}_{9}$ compound.

\subsection{Enthalpy of formation using high temperature oxide melt solution calorimetry}

Standard molar enthalpy of formation of $\mathrm{Ba}_{3} \mathrm{SrNb}_{2} \mathrm{O}_{9}(\mathrm{~s})$ sample was derived from the enthalpy of dissolution data of the compound and its component oxides viz., $\mathrm{BaO}(\mathrm{s})$, $\mathrm{SrO}(\mathrm{s})$ and $\mathrm{Nb}_{2} \mathrm{O}_{5}(\mathrm{~s})$ in molten $\mathrm{PbO}+\mathrm{B}_{2} \mathrm{O}_{3}(2: 1$ molar ratio) solvent maintained at $966 \mathrm{~K}$. Since alkaline earth oxide MO (where $\mathrm{M}=\mathrm{Ba} / \mathrm{Sr}$ ) is highly hygroscopic and reactive material, the value of molar enthalpy of dissolution of $\mathrm{MO}(\mathrm{s})$ was therefore, obtained indirectly using a separate thermo chemical cycle employing enthalpy of dissolution of their carbonates $\mathrm{MCO}_{3}(\mathrm{~s})$. The details of the experimental measurements have been described elsewhere [14]. Table 3 gives the thermo-chemical cycle for derivation of standard molar enthalpies of dissolution of MO (s, 298K). The enthalpies of decomposition of alkaline earth carbonate, $\Delta_{\text {decom }} H\left(\mathrm{MCO}_{3}\right)$, for $\mathrm{BaCO}_{3}$ and $\mathrm{SrCO}_{3}$ are $-269.2 \mathrm{~kJ} \cdot \mathrm{mol}^{-1}$ and $-234.3 \mathrm{~kJ} \cdot \mathrm{mol}^{-1}$, respectively. The value of enthalpy increment of $\mathrm{CO}_{2}(\mathrm{~g})$ was taken from literature and is equal to $32 \mathrm{~kJ} \cdot \mathrm{mol}^{-1}$ [16]. Enthalpy increments for carbonates are measured at the same experimental temperature and are used for the calculation. The enthalpy of solution of $\mathrm{BaO}$ and $\mathrm{SrO}$, when added from $298.15 \mathrm{~K}, \Delta_{\mathrm{ds}} H(\mathrm{MO})$, also known as enthalpy of drop solution, is calculated to be 93.3 and $-59.5 \mathrm{~kJ} \cdot \mathrm{mol}^{-1}$. The enthalpy of solution of the $\mathrm{Nb}_{2} \mathrm{O}_{5}(\mathrm{~s})$ in liquid $\mathrm{PbO}+\mathrm{B}_{2} \mathrm{O}_{3}(2: 1)$ solvent at $966 \mathrm{~K}$ at infinite dilution was measured for few successive additions and presented in Table 4.

Table 3. Standard molar enthalpies of dissolution of $\mathrm{MO}(\mathrm{s}$, $298 \mathrm{~K}$ ) (where $\mathrm{M=Ba} / \mathrm{Sr}$ ); sol= molten $\mathrm{PbO}+\mathrm{B}_{2} \mathrm{O}_{3}(2: 1)$ solvent at $966 \mathrm{~K} ; \Delta_{d s} H^{o}{ }_{298}(M O)=\Delta H_{1}+\Delta H_{2}+\Delta H_{3}$.

\begin{tabular}{lll}
\hline Reactions & $\Delta H_{\mathrm{i}}$ & Ref. \\
\hline $\begin{array}{l}\mathrm{MCO}_{3}(\mathrm{~s}, 298 \mathrm{~K})+\mathrm{sol}(\mathrm{T} \mathrm{K})= \\
(\mathrm{MO}) \mathrm{sol}(\mathrm{T} \mathrm{K})+\mathrm{CO}_{2}(\mathrm{~g}, \mathrm{~T})\end{array}$ & $\Delta H_{1}$ & This \\
$\mathrm{MO}(\mathrm{s}, 298 \mathrm{~K})+\mathrm{CO}_{2}(\mathrm{~g}, 298$ & $\Delta H_{2}$ & Work \\
$\mathrm{K})=\mathrm{MCO}_{3}(\mathrm{~s}, 298 \mathrm{~K})$ & & Ref. [16] \\
$\mathrm{CO}_{2}(\mathrm{~g}, \mathrm{~T} \mathrm{~K})=\mathrm{CO}_{2}(\mathrm{~s}, 298 \mathrm{~K})$ & $\Delta H_{3}$ & Ref. [16] \\
\hline $\begin{array}{l}\mathrm{MO}(\mathrm{s}, 298 \mathrm{~K})+\operatorname{sol}(\mathrm{T} \mathrm{K})= \\
(\mathrm{MO})_{\mathrm{sol}}(\mathrm{T} \mathrm{K})\end{array}$ & $\Delta_{\mathrm{ds}} H^{\mathrm{o}}{ }_{298}$ & This \\
\hline
\end{tabular}

The calculated values of enthalpy of drop solution of $\mathrm{BaO}$ and $\mathrm{SrO}$, obtained from present experiment using lead borate solvent and other literature data using lead borate solvent and sodium molybdate solvent are given in Table 5.
The enthalpy of solution of $\mathrm{Nb}_{2} \mathrm{O}_{5}$ in lead borate solvent is not available in literature to the best of our knowledge. The values of enthalpy of drop-solution of $\mathrm{Nb}_{2} \mathrm{O}_{5}$ in lead borate solvent and in sodium molybdate solvent are compared in Table 5. It indicates that enthalpy of dropsolution of $\mathrm{Nb}_{2} \mathrm{O}_{5}$ in lead borate solvent is more exothermic than that in the sodium molybdate solvent. However, the dissolution of $\mathrm{Nb}_{2} \mathrm{O}_{5}$ in both the solvent is slow.

Table 4. The molar enthalpy of dissolution of $\mathrm{Ba}_{3} \mathrm{SrNb}_{2} \mathrm{O}_{9}(s)$ and $\mathrm{Nb}_{2} \mathrm{O}_{5}(\mathrm{~s})$ in molten $\mathrm{PbO}+\mathrm{B}_{2} \mathrm{O}_{3}(2: 1$ molar ratio) solvent maintained at $966.1 \pm 0.1 \mathrm{~K}$ and $P$ $=0.1 \mathrm{MPa} ; \Delta_{d s} H_{m}=$ molar enthalpy of drop solution.

\begin{tabular}{lll}
\hline Solute & $\begin{array}{l}\text { Mass } \\
/ \mathrm{mg}\end{array}$ & $\begin{array}{l}\Delta_{\mathrm{ds}} H \\
/ \mathrm{kJ} \cdot \mathrm{mol}^{-1}\end{array}$ \\
\hline $\mathrm{Ba}_{3} \mathrm{SrNb}_{2} \mathrm{O}_{9}(\mathrm{~s})$ & 11.2 & 341.5 \\
Mol. Mass & 11.1 & 343.2 \\
$=829.41 \mathrm{~g} \cdot \mathrm{mol}^{-1}$ & 11.1 & 343.9 \\
& 11.3 & 344.0 \\
& 11.3 & 343.9 \\
& 11.4 & 344.1 \\
& & Mean: $344.5 \pm 3.5$ \\
\hline $\mathrm{Nb}_{2} \mathrm{O}_{5}(\mathrm{~s})$ & 10.4 & 68.1 \\
$\mathrm{Mol}^{\text {Mass }}$ & 11.8 & 65.0 \\
$=265.81 \mathrm{~g} \cdot \mathrm{mol}^{-1}$ & 11.4 & 66.5 \\
& 10.6 & 66.6 \\
& 10.3 & 66.3 \\
& 11.6 & 65.6 \\
& & Mean: $66.6 \pm 1.9$ \\
\hline
\end{tabular}

In present experiments, enthalpy of drop solution of the $\mathrm{Ba}_{3} \mathrm{SrNb}_{2} \mathrm{O}_{9}$ (s) compound in liquid $\mathrm{PbO}+\mathrm{B}_{2} \mathrm{O}_{3}$ (2:1) solvent at $T=966 \mathrm{~K}$ at infinite dilution was and given in Table 4

The values of enthalpies of solution of the compound are composition independent and random in nature. This indicates that there is no significant dilution effect and the infinite dilution condition is maintained during each experiment.

Table 5. Comparison of enthalpy of drop-solution $\left(\Delta_{d s} H\right)$ of $\mathrm{BaO}, \mathrm{SrO}$ and $\mathrm{Nb}_{2} \mathrm{O}_{5}$ in different solvent. The error is twice the standard deviation of the mean.

\begin{tabular}{lll}
\hline $\begin{array}{l}\text { Compo } \\
\text { und }\end{array}$ & $\begin{array}{l}\mathrm{\Delta ds}_{\mathrm{ds}} \mathrm{H} / \mathrm{kJ} \cdot \mathrm{mol}^{-1} \text { in } \\
\left(2 \mathrm{PbO}+\mathrm{B}_{2} \mathrm{O}_{3}\right) \text { solvent }\end{array}$ & $\begin{array}{l}\mathrm{\Delta}_{\mathrm{ds}} \mathrm{H} / \mathrm{kJ} \cdot \mathrm{mol}^{-1} \text { in } \\
\left(3 \mathrm{Na}_{2} \mathrm{O}+4 \mathrm{MoO}_{3}\right) \\
\text { solvent }\end{array}$ \\
\hline $\mathrm{BaO}$ & $\begin{array}{l}-94.2 \pm 1.7 \text { at } 966 \mathrm{~K} \text { [This } \\
\text { study] }\end{array}$ & \\
& $-90.8 \pm 2.2$ at $975 \mathrm{~K} \mathrm{[18]}$ & \\
$\mathrm{SrO}$ & $-59.5 \pm 1.69$ at $966 \mathrm{~K}[\mathrm{This}$ & -134.47 at $973 \mathrm{~K} \mathrm{[20]}$ \\
& study] & $-135.82 \pm 2.5$ at $975 \mathrm{~K}$ \\
& $-60.5 \pm 2.0$ at $975 \mathrm{~K}[19]$ & {$[21]$} \\
& & $-131.42 \pm 1.9$ at $975 \mathrm{~K}$ \\
& & {$[22]$} \\
$\mathrm{Nb}_{2} \mathrm{O}_{5}$ & $66.6 \pm 1.9$ at $975 \mathrm{~K}[\mathrm{This}$ & -129.25 at $1073 \mathrm{~K}[23]$ \\
& study] & $141.8 \pm 6.0$ at $1073 \mathrm{~K}$ \\
& & {$[20]$} \\
& & $91.97 \pm 0.78$ at $973 \mathrm{~K}$ \\
& & \\
\hline
\end{tabular}

Thermodynamic cycles were constructed to calculate the enthalpy of formation of $\mathrm{Ba}_{3} \mathrm{SrNb}_{2} \mathrm{O}_{9}$ from the elements and are presented in Table 6 . The $\Delta_{\mathrm{f}} H_{\mathrm{m}}^{0}(298.15 \mathrm{~K})$ of the compound from the elements is $-4772.2 \pm 5.1 \mathrm{~kJ} \cdot \mathrm{mol}^{-1}$. Enthalpy of formation of the component oxides, $\mathrm{BaO}(\mathrm{s})$, $\mathrm{SrO}(\mathrm{s})$ and $\mathrm{Nb}_{2} \mathrm{O}_{5}(\mathrm{~s})$ are taken from ref. [16]. 
The standard molar entropy of compound at $298 \mathrm{~K}, \mathrm{~S}^{0}{ }_{298}$ $\left(\mathrm{Ba}_{3} \mathrm{SrNb}_{2} \mathrm{O}_{9}(\mathrm{~s})\right)$, has been estimated by adding the standard molar entropies $\left(\mathrm{S}^{0}{ }_{298}\right)$ of component oxides, viz. $\mathrm{BaO}(\mathrm{s})$, $\mathrm{SrO}(\mathrm{s}), \mathrm{Nb}_{2} \mathrm{O}_{5}(\mathrm{~s})$ in their molar ratio, from the literature [16]. The entropy $\left(\mathrm{S}^{0}{ }_{298}\right)$ value at $298 \mathrm{~K}$ estimated in this study is $404.1 \mathrm{~J} \cdot \mathrm{K} \cdot \mathrm{mol}^{-1}$, the enthalpy of formation of $\mathrm{Ba}_{3} \mathrm{SrNb}_{2} \mathrm{O}_{9}$ (s) from its constituent elements $(-4772.2$ $\left.\mathrm{kJ} \cdot \mathrm{mol}^{-1}\right)$ [This Study], and the entropies of $\mathrm{Ba}(62.42$ $\left.\mathrm{J} \cdot \mathrm{K} \cdot \mathrm{mol}^{-1}\right) \quad[16], \quad \operatorname{Sr}\left(55.69 \mathrm{~J} \cdot \mathrm{K} \cdot \mathrm{mol}^{-1}\right) \quad[16], \quad \mathrm{Nb}(36.40$ $\left.\mathrm{J} \cdot \mathrm{K} \cdot \mathrm{mol}^{-1}\right)[16]$ and $\mathrm{O}_{2}\left(205.04 \mathrm{~J} \cdot \mathrm{K} \cdot \mathrm{mol}^{-1}\right)[16]$ were used to calculate the standard Gibbs energy of formation of $\mathrm{Ba}_{3} \mathrm{SrNb}_{2} \mathrm{O}_{9}(\mathrm{~s})$ :

$\Delta_{\mathrm{f}} G_{298}^{0}\left(\mathrm{Ba}_{3} \mathrm{SrNb}_{2} \mathrm{O}_{9}(\mathrm{~s})\right)=\Delta_{\mathrm{f}} H^{0}{ }_{298}\left(\mathrm{Ba}_{3} \mathrm{SrNb}_{2} \mathrm{O}_{9}(\mathrm{~s})\right)-$ $298 \times 0.001 \times\left[\mathrm{S}^{0}{ }_{298}\left(\mathrm{Ba}_{3} \mathrm{SrNb}_{2} \mathrm{O}_{9}(\mathrm{~s})\right) \quad-\quad 3 \times \mathrm{S}^{0}{ }_{298}(\mathrm{Ba}(\mathrm{s}))-\right.$ $\left.\mathrm{S}^{0}{ }_{298}(\mathrm{Sr}(\mathrm{s}))-2 \times \mathrm{S}^{0}{ }_{298}(\mathrm{Nb}(\mathrm{s}))-4.5 \times \mathrm{S}^{0}{ }_{298}\left(\mathrm{O}_{2}(\mathrm{~g})\right)\right]$

$=-4523.4 \mathrm{~kJ} \cdot \mathrm{mol}^{-1}$

The standard molar enthalpy of formation of $\mathrm{Ba}_{3} \mathrm{SrNb}_{2} \mathrm{O}_{9}$ (s) with respect to the constituent oxides (i.e., $\mathrm{BaO}, \mathrm{SrO}$ and $\mathrm{Nb}_{2} \mathrm{O}_{5}$ ) at $298 \mathrm{~K}$ is found to-620.2 $\mathrm{kJ} \cdot \mathrm{mol}^{-1}$. This indicates that $\mathrm{Ba}_{3} \mathrm{SrNb}_{2} \mathrm{O}_{9}$ (s) is relatively more stable compared to its binary oxides.

\section{Thermal function of the $\mathrm{Ba}_{3} \mathrm{SrNb}_{2} \mathrm{O}_{9}$ compound}

The standard molar enthalpy of formation of $\mathrm{Ba}_{3} \mathrm{SrNb}_{2} \mathrm{O}_{9}$ (s) determined by high-temperature calorimetric technique is listed in Table 7. The smoothed values of measured heat capacity at regular interval of temperature were used to estimate the standard molar entropy and enthalpy for $\mathrm{Ba}_{3} \mathrm{SrNb}_{2} \mathrm{O}_{9}(\mathrm{~s})$. The standard molar entropy and enthalpy for $\mathrm{Ba}_{3} \mathrm{SrNb}_{2} \mathrm{O}_{9}(\mathrm{~s})$ are related to heat capacity as per the relation (3) and (4) respectively.

$$
\begin{aligned}
& S^{0}{ }_{T \mathrm{~K}}\left(\mathrm{Ba}_{3} \mathrm{SrNb}_{2} \mathrm{O}_{9}\right)-S_{298 \mathrm{~K}}^{0}\left(\mathrm{Ba}_{3} \mathrm{SrNb}_{2} \mathrm{O}_{9}\right) \\
& =\int^{T \mathrm{~K}}{ }_{298 \mathrm{~K}}\left(C_{\mathrm{p}}^{0}\left(\mathrm{Ba}_{3} \mathrm{SrNb}_{2} \mathrm{O}_{9}\right) / T\right) \mathrm{d} T \\
& \Delta H^{0}{ }_{T \mathrm{~K}}\left(\mathrm{Ba}_{3} \mathrm{SrNb}_{2} \mathrm{O}_{9}\right)-\Delta H^{0}{ }_{298 \mathrm{~K}}\left(\mathrm{Ba}_{3} \mathrm{SrNb}_{2} \mathrm{O}_{9}\right) \\
& =\int^{T \mathrm{~K}_{298 \mathrm{~K}}} C_{\mathrm{p}}{ }^{0}\left(\mathrm{Ba}_{3} \mathrm{SrNb}_{2} \mathrm{O}_{9}\right) \mathrm{d} T
\end{aligned}
$$

The calculated values of these thermodynamic functions have been presented in Table 7, and have an uncertainty of within $\pm 2-3 \%$. It is evident that the entropy and enthalpy changes gradually increase with temperature and thus mimic the signature of the non-magnetic compounds. The standard molar entropy of $\mathrm{Ba}_{3} \mathrm{SrNb}_{2} \mathrm{O}_{9}$ (s) was estimated by adding the standard molar entropies of component oxides in their respective molar ratio from the literature [16].

Free energy function (FEF) for compound can be derived using the following "Eq. (5)":

$\mathrm{FEF}=-\left[\left(H^{0}{ }_{T}-H^{0}{ }_{298}\right) / T\right]+S^{0}{ }_{T}$

The Free energy function (FEF) of the compound also listed in Table 7 as a function of temperature. Uncertainties for thermodynamic functions were calculated as twice the

\begin{tabular}{|c|c|}
\hline Reactions & $\begin{array}{l}\text { Enthalpy per } \\
\text { mole }\end{array}$ \\
\hline $\mathrm{Ba}_{3} \mathrm{SrNb}_{2} \mathrm{O}_{9}(\mathrm{~s}, 298 \mathrm{~K}) \rightarrow 3 \mathrm{BaO}($ dis, $966 \mathrm{~K})+\mathrm{SrO}($ dis, $966 \mathrm{~K})+\mathrm{Nb}_{2} \mathrm{O}_{5}($ dis, $966 \mathrm{~K})$ & $\Delta H_{1}$ \\
\hline $3 \mathrm{BaO}(\mathrm{s}, 298 \mathrm{~K}) \rightarrow 3 \mathrm{BaO}(\mathrm{dis}, 966 \mathrm{~K})$ & $\Delta H_{2}$ \\
\hline $\mathrm{SrO}(\mathrm{s}, 298 \mathrm{~K}) \rightarrow \mathrm{SrO}($ dis, $966 \mathrm{~K})$ & $\Delta H_{3}$ \\
\hline $\mathrm{Nb}_{2} \mathrm{O}_{5}(\mathrm{~s}, 298 \mathrm{~K}) \rightarrow \mathrm{Nb}_{2} \mathrm{O}_{5}(\mathrm{dis}, 966 \mathrm{~K})$ & $\Delta H_{4}$ \\
\hline $\mathrm{Ba}(\mathrm{s}, 298 \mathrm{~K})+0.5 \mathrm{O}_{2}(\mathrm{~g}, 298 \mathrm{~K}) \rightarrow \mathrm{BaO}(\mathrm{s}, 298 \mathrm{~K})$ & $\Delta H_{5}$ \\
\hline $\mathrm{Sr}(\mathrm{s}, 298 \mathrm{~K})+0.5 \mathrm{O}_{2}(\mathrm{~g}, 298 \mathrm{~K}) \rightarrow \mathrm{SrO}(\mathrm{s}, 298 \mathrm{~K})$ & $\Delta H_{6}$ \\
\hline $2 \mathrm{Nb}(\mathrm{s}, 298 \mathrm{~K})+2.5 \mathrm{O}_{2}(\mathrm{~g}, 298 \mathrm{~K}) \rightarrow \mathrm{Nb}_{2} \mathrm{O}_{5}(\mathrm{~s}, 298 \mathrm{~K})$ & $\Delta H_{7}$ \\
\hline \multicolumn{2}{|l|}{$3 \mathrm{Ba}(\mathrm{s}, 298 \mathrm{~K})+\mathrm{Sr}(\mathrm{s}, 298 \mathrm{~K})+2 \mathrm{Nb}(\mathrm{s}, 298 \mathrm{~K})+4.5 \mathrm{O}_{2}(\mathrm{~s}, 298 \mathrm{~K})$} \\
\hline \multicolumn{2}{|c|}{ Hence, $\Delta_{\mathrm{f}} H_{\mathrm{m}}^{\mathrm{o}}$ at $298 \mathrm{~K}$ of $\mathrm{Ba}_{3} \mathrm{SrNb}_{2} \mathrm{O}_{9}=\Delta H_{8}=-\Delta H_{1}+3 \times \Delta H_{2}+\Delta H_{3}+\Delta H_{4}+3 \times \Delta H_{5}+\Delta H_{6}+\Delta H_{7}$} \\
\hline
\end{tabular}
standard deviation $( \pm 2 \sigma)$ of the experimental values.

Table 6. Thermodynamic cycles for the standard molar enthalpy of formation $\left(\Delta_{f} \mathrm{H}_{m}^{\circ}\right.$ at $\left.298 \mathrm{~K}\right)$ of $\mathrm{Ba}_{3} \mathrm{SrNb}_{2} \mathrm{O}_{9}(\mathrm{~s})$ from elements.

Table 7. Thermodynamic functions for the compound $\mathrm{Ba}_{3} \mathrm{SrNb}_{2} \mathrm{O}_{9}(s)$.

\begin{tabular}{llllll}
\hline$T / \mathrm{K}$ & $\begin{array}{l}\text { Fitted } C_{p}^{o} \\
/ \mathrm{J} \cdot \mathrm{K}^{-1} \cdot \mathrm{mol}^{-1}\end{array}$ & $\begin{array}{l}N K C^{o} \\
/ \mathrm{J} \cdot \mathrm{K}^{-1} \cdot \mathrm{mol}^{-1}\end{array}$ & $\begin{array}{l}\left(S_{T}^{o}-S^{o}{ }_{298.15}\right) \\
/ \mathrm{J} \cdot \mathrm{K}^{-1} \cdot \mathrm{mol}^{-1}\end{array}$ & $\begin{array}{l}\left(H_{T}^{o}-H^{o}{ }_{298.15}\right) \\
/ \mathrm{kJ} \cdot \mathrm{mol}^{-1}\end{array}$ & $f e f / \mathrm{J} \cdot \mathrm{K}^{-1} \cdot \mathrm{mol}^{-1}$ \\
\hline 298 & 318.1 & 319.3 & 0 & 0 & 404.1 \\
300 & 318.8 & 319.8 & 2.1 & 0.64 & 404.1 \\
400 & 345.6 & 343.1 & 97.9 & 33.99 & 417.0 \\
500 & 362.1 & 359.9 & 176.9 & 69.43 & 442.2 \\
600 & 374.4 & 372.5 & 244.1 & 106.28 & 471.0 \\
700 & 384.8 & 382.4 & 302.6 & 144.25 & 500.6 \\
800 & 394.2 & 390.5 & 354.6 & 183.21 & 529.7 \\
900 & 402.9 & 397.3 & 401.6 & 223.07 & 557.8 \\
1000 & 411.3 & 403.1 & 444.4 & 263.79 & 584.7 \\
\hline
\end{tabular}




\section{Conclusions}

Standard enthalpy of formation of $\mathrm{Ba}_{3} \mathrm{SrNb}_{2} \mathrm{O}_{9}(\mathrm{~s})$ is determined employing oxide melt solution calorimeter for the first time and is found to be $-4772.2 \pm 5.1 \mathrm{~kJ} \cdot \mathrm{mol}^{-1}$. The molar heat capacity and enthalpy increment of the $\mathrm{Ba}_{3} \mathrm{SrNb}_{2} \mathrm{O}_{9}(\mathrm{~s})$ is measured using DSC and high temperature isothermal calorimeter, respectively. The standard molar heat capacity of $\mathrm{Ba}_{3} \mathrm{SrNb}_{2} \mathrm{O}_{9}(\mathrm{~s})$ derived from the measured $\left(H_{T}-H_{298}\right)$ values and data obtained from DSC experiment are in good agreement with each other and given in the Table 7. Smoothed heat capacities values are used for the calculation of the thermodynamic table. The values of standard thermodynamic functions for $\mathrm{Ba}_{3} \mathrm{SrNb}_{2} \mathrm{O}_{9}(\mathrm{~s})$ at $T=298 \mathrm{~K}$ are: $C_{\mathrm{p}, \mathrm{m}}^{\mathrm{o}}(298 \mathrm{~K})=318.1 \mathrm{~J} \cdot \mathrm{K}$

\section{References}

[1] J. Leitner, M. Hampl, K. Růžička, M. Straka, D. Sedmidubský, P. Svoboda., "Heat capacity, enthalpy and entropy of strontium niobate $\mathrm{Sr}_{2} \mathrm{Nb}_{2} \mathrm{O}_{7}$ and calcium niobate $\mathrm{Ca}_{2} \mathrm{Nb}_{2} \mathrm{O}_{7}, "$ Thermochim. Acta., 475(1), 33-38, 2008

[2] M. Weiden, A. Grauel, J. Norwig, S. Horn, F Steglich, "Crystalline structure of the strontium niobates $\mathrm{Sr}_{4} \mathrm{Nb}_{2} \mathrm{O}_{9}$ and $\mathrm{Sr}_{5} \mathrm{Nb}_{4} \mathrm{O}_{15}$," J. Alloy Compd., 218, 13-16, 1995.

[3] P.K. Bajpai, K.N. Singh, "Dielectric relaxation and ac conductivity study of $\mathrm{Ba}\left(\mathrm{Sr}_{1 / 3} \mathrm{Nb}_{2 / 3}\right) \mathrm{O}_{3}$," Physica $B$. Condensed Matter; 406, 1226-1232, 2011.

[4] H. Sreemoolanadhan, M.T. Sebastian, P. Mohanan, "High permittivity and low loss ceramics in the $\mathrm{BaO}$ $\mathrm{SrO}-\mathrm{Nb}_{2} \mathrm{O}_{5}$ system," Mater. Res. Bull., 30, 653-658, 1995.

[5] Rajan Jose, Takenobu Suzuki, Yasutake Ohishi, "Thermal and optical properties of $\mathrm{TeO}_{2}-\mathrm{BaO}-\mathrm{SrO}$ $\mathrm{Nb}_{2} \mathrm{O}_{5}$ based glasses: New broadband Raman gain media", J. Non-Cryst. Solids., 352, 5564-5571, 2006.

[6] L. Marta, M. ZaharescuIov, Haidu C. Gh. Macarovici, "Thermal synthesis of Barium and Barium-Strontium metaniobates by using a coprecipitation method," $J$. Therm. Anal. Calorim., 28, 175-188, 1983.

[7] Verma Maya, Tanwar Amit, Sreenivas K., "Phase evolution of strontium bismuth niobate ceramics by conventional solid-state reaction method," J. Therm. Anal. Calorim., 135, 2077-2087, 2019.

[8] Ismunandar, B.J. Kennedy, Gunawan, Marsongkohardi, "Structure of $\mathrm{ABi}_{2} \mathrm{Nb}_{2} \mathrm{O}_{9}(\mathrm{~A}=\mathrm{Sr}$, $\mathrm{Ba})$ : refinement of powder neutron diffraction data," J. Solid State Chem., 126, 135-141, 1996.

[9] W. Wu, S. Liang, X. Wang, J. Bi, P. Liu, L. Wu, "Synthesis, structures and photocatalytic activities of microcrystalline $\mathrm{ABi}_{2} \mathrm{Nb}_{2} \mathrm{O}_{9}(\mathrm{~A}=\mathrm{Sr}, \mathrm{Ba})$ powders," $J$. Solid State Chem., 184, 81-88, 2011.

[10] V.M. Zhukovsky, A.L. Podkorytov, "Investigation of $\mathrm{s}$, p, d-element niobates and their solid solution formation processes by thermal analysis." J. Therm. Anal. Calorim., 60, 523-534, 2000.

[11] J. R. Carruthers and M. Grasso, "Phase Equilibria Relations in the Ternary System $\mathrm{BaO}-\mathrm{SrO}$ $\mathrm{Nb}_{2} \mathrm{O}_{5}, "$ J. Electrochem. Soc. 117, 1426-1432, 1970.

[12] R. Ratheesh, M. Sreemoolanadhan, T. Sebastian, "Vibrational Analysis of $\mathrm{Ba}_{5-} \mathrm{Sr}_{\mathrm{x}} \mathrm{Nb}_{4} \mathrm{O}_{15}$ Microwave Dielectric Ceramic Resonators," J. Solid State Chem., 131, 2-8, 1997

[13] H. W. Zandbergen, D.J.W. Ijdo, "Barium strontium
${ }^{1} \cdot \mathrm{mol}^{-1} ; \Delta_{\mathrm{f}} H^{\mathrm{o}}{ }_{\mathrm{m}}(298 \mathrm{~K})=-4772.2 \mathrm{~kJ} \cdot \mathrm{mol}^{-1} ; \Delta_{\mathrm{f}} G^{\mathrm{o}}{ }_{\mathrm{m}}(298 \mathrm{~K})=$ - $4523.4 \mathrm{~kJ} \cdot \mathrm{mol}^{-1}$; fef $(298 \mathrm{~K})=404.1 \mathrm{~J} \cdot \mathrm{K}^{-1} \cdot \mathrm{mol}^{-1}$. These data, therefore, are important for assessment of fission product interactions and for modeling of fuel thermodynamics which plays an important role in predicting long term stability of these materials under different reactive conditions. Enthalpy of formation and Gibbs energy formation data for this compound would be useful for predicting the stability of the compound in different physico-chemical conditions. The standard entropy of $\mathrm{Ba}_{3} \mathrm{SrNb}_{2} \mathrm{O}_{9}$ (s) derived in this study can be obtained more accurately from the low temperature heat capacity measurement.

niobate and barium strontium tantalate, $\mathrm{Ba}_{3} \mathrm{SrNb}_{2} \mathrm{O}_{9}$ and $\mathrm{Ba}_{3} \mathrm{SrTa}_{2} \mathrm{O}_{9}$, a Rietveld refinement of neutron powder diffraction data," Acta. Cryst., C39, 829-832, 1983.

[14] A. Navrotsky, "Progress and new directions in high temperature calorimetry," Phys. Chem. Miner., 2, 89104, 1977.

[15] M.W. Chase Jr. et al., "JANAF Thermochemical Tables," 4th ed., J. Phys. Chem. Ref. Data 23 Monograph No. 9, 1995.

[16] I. Barin, "Thermochemical Data of Pure Substances," vol. I \& II, 3rd ed., VCH Publishers, New York, 1995.

[17] PCPDFWIN Version 2.2, 2001 JCPDS-ICDD.

[18] J. Dicarlo, I. Yazdi, J.A. Jacobson, A. Navrotsky, "Preparation and thermochemical properties of $\mathrm{BaNiO}_{2+x}$," J. Solid State Chem., 109, 223-226, 1994.

[19] Bularzik Joseph, Navrotsky Alexandra, Dicarlo Joseph, "Energetics of $\mathrm{La}_{2-x} \mathrm{Sr}_{x} \mathrm{CuO}_{4-x}$ Solid Solutions $(0.0<x<1.0)$," J. Solid State Chem.; 93, 418-429, 1991.

[20] J. Leitner, M. Nevřiva, D. Sedmidubský, P. Voňka, "Enthalpy of formation of selected mixed oxides in a CaO-SrO- $\mathrm{Bi}_{2} \mathrm{O}_{3}-\mathrm{Nb}_{2} \mathrm{O}_{5}$ system," J. Alloy Compd., 509, 4940-4943, 2011.

[21] J. Cheng, A. Navrotsky, "Energetics of Magnesium, Strontium, and Barium Doped Lanthanum Gallate Perovskites." J. Solid State Chem. 177, 126-133, 2004.

[22] H. Xu, A. Navrotsky, Y. Su, M.L. Balmer, "Perovskite Solid Solutions along the $\mathrm{NaNbO}_{3}-\mathrm{SrTiO}_{3}$ Join: Phase Transitions, Formation Enthalpies and Implications for General Perovskite Energetics." Chem. Mater. 17, 1880-1886, 2005.

[23] J. Leitner, I. Sipula, K. Ruzicka, D. Sedmidubsky, P. Svoboda, "Heat capacity, enthalpy and entropy of strontium niobates $\mathrm{Sr}_{2} \mathrm{Nb}_{10} \mathrm{O}_{27}$ and $\mathrm{Sr}_{5} \mathrm{Nb}_{4} \mathrm{O}_{15}$," $J$. Alloys Compd. 481, 35-39, 2009.

[24] I. Pozdnyakova, A.Navrotsky, L. Shilkina, L. Reznitchenko, "Thermodynamic and structural properties of sodium lithium niobate solid solutions." J. Am. Ceram. Soc. 85, 379-384, 2002. 